\title{
Source-receptor relationships between East Asian sulfur dioxide emissions and Northern Hemisphere sulfate concentrations
}

\author{
J. Liu ${ }^{1}$, D. L. Mauzerall ${ }^{1}$, and L. W. Horowitz ${ }^{2}$ \\ ${ }^{1}$ Woodrow Wilson School of Public and International Affairs, Princeton University, Princeton, NJ, USA \\ ${ }^{2}$ Geophysical Fluid Dynamics Laboratory, Princeton, NJ, USA
}

Received: 18 January 2008 - Published in Atmos. Chem. Phys. Discuss.: 18 March 2008

Revised: 10 June 2008 - Accepted: 10 June 2008 - Published: 15 July 2008

\begin{abstract}
We analyze the effect of varying East Asian (EA) sulfur emissions on sulfate concentrations in the Northern Hemisphere, using a global coupled oxidant-aerosol model (MOZART-2). We conduct a base and five sensitivity simulations, in which sulfur emissions from each continent are tagged, to establish the source-receptor (S-R) relationship between EA sulfur emissions and sulfate concentrations over source and downwind regions. We find that from west to east across the North Pacific, EA sulfate contributes approximately $80 \%-20 \%$ of sulfate at the surface, but at least $50 \%$ at $500 \mathrm{hPa}$. Surface sulfate concentrations are dominated by local anthropogenic sources. Of the sulfate produced from sources other than local anthropogenic emissions (defined here as "background" sulfate), EA sources account for approximately $30 \%-50 \%$ (over the Western US) and 10\%$20 \%$ (over the Eastern US). The surface concentrations of sulfate from EA sources over the Western US are highest in MAM (up to $0.15 \mu \mathrm{g} / \mathrm{m}^{3}$ ), and lowest in DJF (less than $\left.0.06 \mu \mathrm{g} / \mathrm{m}^{3}\right)$. Reducing EA $\mathrm{SO}_{2}$ emissions will significantly decrease the spatial extent of the EA sulfate influence (represented by the areas where at least $0.1 \mu \mathrm{g} \mathrm{m}^{-3}$ of sulfate originates from EA) over the North Pacific both at the surface and at $500 \mathrm{hPa}$ in all seasons, but the extent of influence is insensitive to emission increases, particularly in DJF and JJA. We find that EA sulfate concentrations over most downwind regions respond nearly linearly to changes in $\mathrm{EA} \mathrm{SO}_{2}$ emissions, but sulfate concentrations over the EA source region increase more slowly than $\mathrm{SO}_{2}$ emissions, particularly at the surface and in winter, due to limited availability of oxidants (in particular of $\mathrm{H}_{2} \mathrm{O}_{2}$, which oxidizes $\mathrm{SO}_{2}$ to sulfate in the aqueous phase). We find that similar estimates of the S-R relationship for trans-Pacific transport of EA sulfate would
\end{abstract}

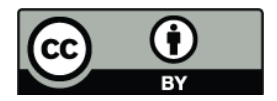

Correspondence to: J. Liu

(jliu@ princeton.edu) be obtained using either sensitivity (i.e., varying emissions from a region to examine the effects on downwind concentrations) or tagging techniques. Our findings suggest that future changes in EA sulfur emissions may cause little change in the sulfate-induced health impact over downwind continents. However, $\mathrm{SO}_{2}$ emission reductions may significantly reduce the sulfate concentrations and the resulting negative radiative forcing over the North Pacific and the United States, thus providing a warming tendency.

\section{Introduction}

Sulfate aerosol is an important component of fine particulate matter $\left(\mathrm{PM}_{2.5}\right.$, diameter $\left.\leq 2.5 \mu \mathrm{m}\right)$. $\mathrm{PM}_{2.5}$ concentrations are associated, without a threshold, with increased risk of adverse health outcomes including premature mortality (Pope et al., 2002; Pope et al., 2004; Schwartz et al., 2008). In addition, sulfate aerosols scatter sunlight, reduce visibility, affect regional climate, and harm ecosystems (Gunther, 1992; Giorgi et al., 2003; Park et al., 2004; Marmer et al., 2007; Koch et al., 2007a). Sulfate aerosols are produced by gas phase oxidation of $\mathrm{SO}_{2}$ by $\mathrm{OH}$ radicals and by aqueous phase oxidation of $\mathrm{SO}_{2}$ by $\mathrm{H}_{2} \mathrm{O}_{2}$ (Martin and Damschen, 1981) and $\mathrm{O}_{3}$ (Feichter et al., 1996). Since oxidation of $\mathrm{SO}_{2}$ leads to the production of sulfate aerosols and contributes to acid deposition, many industrialized nations have stringently regulated $\mathrm{SO}_{2}$ emissions to protect human health and ecosystems (Dutkiewicz et al., 2000; Moldan et al., 2001). However, the benefits of sulfur emission control partly depend on the linearity of the source-receptor (S-R) relationship between $\mathrm{SO}_{2}$ emissions and sulfate concentrations (Oppenheimer et al., 1985; Dutkiewicz et al., 2000). Generally, the relationship between $\mathrm{SO}_{2}$ emissions and sulfate concentrations is linear near minor $\mathrm{SO}_{2}$ sources, but nonlinear near

Published by Copernicus Publications on behalf of the European Geosciences Union. 


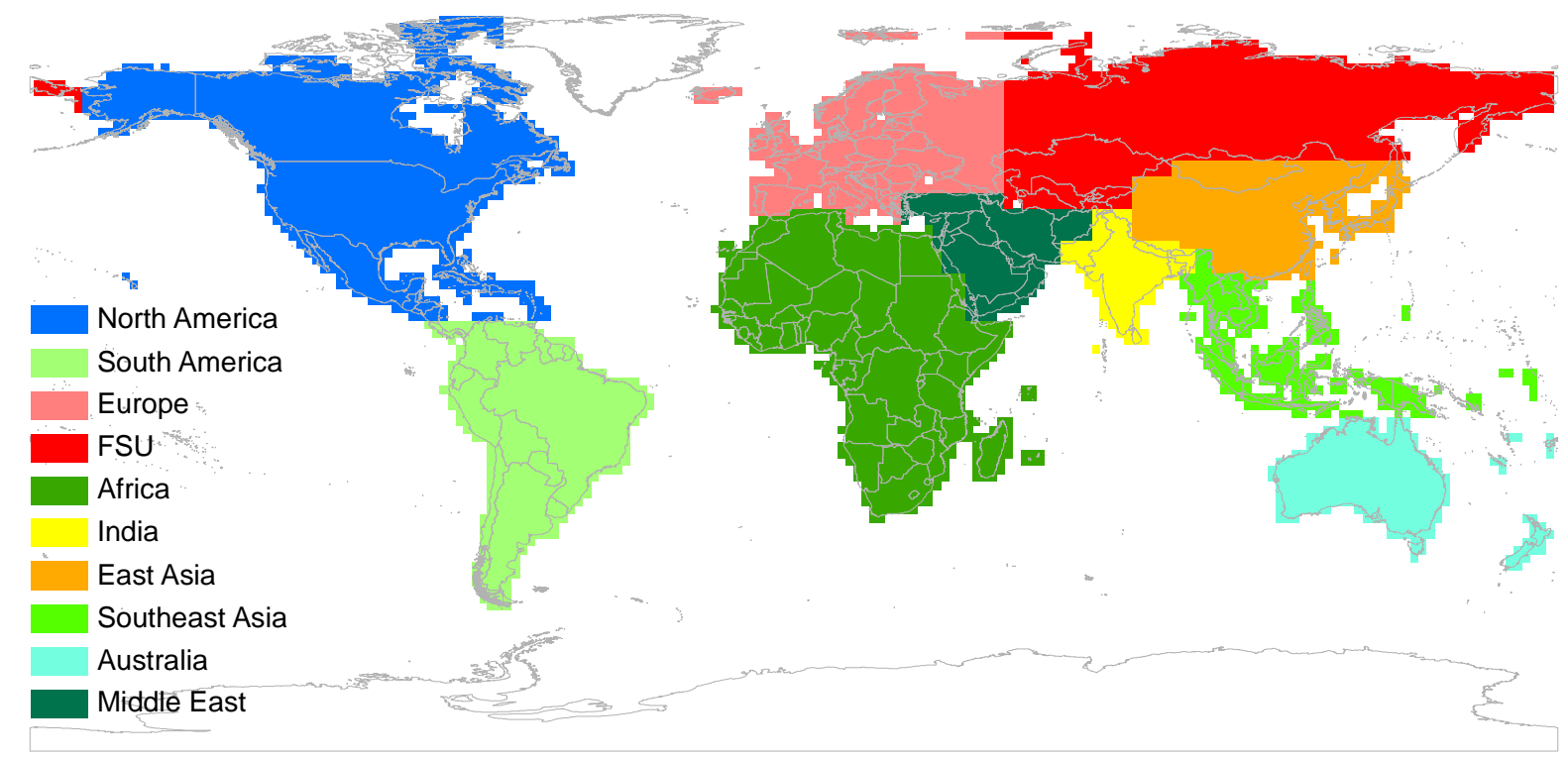

Fig. 1. The ten tagged continental source and receptor regions.

Table 1. Annual sulfur emissions from the ten tagged continental regions (Gmoles/yr).

\begin{tabular}{llllllllll}
\hline NA & SA & EU & FSU & AF & IN & EA & SE & AU & ME \\
\hline 445 & 125 & 717 & 160 & 114 & 75 & 508 & 61 & 24 & 89 \\
\hline
\end{tabular}

major $\mathrm{SO}_{2}$ sources because of limited availability of oxidants (Hilst, 1992; Berglen et al., 2004).

Due to rapid industrialization, anthropogenic $\mathrm{SO}_{2}$ emissions from East Asia (EA), particularly China, have increased substantially in recent decades and between 1990 and 2030 are projected to increase by nearly another $50 \%$ (Klimont et al., 2001). However, China has realized that it is urgent to mitigate $\mathrm{SO}_{2}$ emissions and has designed the Acid Rain and $\mathrm{SO}_{2}$ Pollution Control Program to efficiently control sulfur pollution (Hao et al., 2001). Therefore, future $\mathrm{SO}_{2}$ emissions from EA are highly uncertain and significant increases or decreases are possible (Streets, 2007). These changes underscore the need to establish quantitative S-R relationships between EA $\mathrm{SO}_{2}$ emissions and sulfate concentrations over source and downwind regions.

Typical methods for reducing $\mathrm{SO}_{2}$ emissions include switching fuels or removing sulfur from fuels (e.g., replacing high-sulfur with low-sulfur coal; removing sulfur from gasoline) and reducing end-of-pipe emissions (e.g., installing scrubbers) (Conrad and Kohn, 1996; NAPAP, 2005; Carlson et al., 2000). These strategies have been widely used in the US to reduce $\mathrm{SO}_{2}$ emissions (Carlson et al., 2000), and are believed by the $\mathrm{SO}_{2}$ Pollution Control Program to be affordable strategies to mitigate $\mathrm{SO}_{2}$ emissions in China (Hao et al., 2001). Unlike improving energy efficiency (which re- duces energy use), reducing $\mathrm{SO}_{2}$ emissions by using lowsulfur coal or scrubbers does not reduce other pollutants, such as $\mathrm{NO}_{\mathrm{x}}$ and VOCs (which are the precursors for atmospheric oxidants, such as $\mathrm{OH}, \mathrm{O}_{3}, \mathrm{H}_{2} \mathrm{O}_{2}$ ) or carbon dioxide $\left(\mathrm{CO}_{2}\right)$ the primary greenhouse gas. Therefore, in this study we only change $\mathrm{SO}_{2}$ emissions and leave the emissions of other chemical species unchanged.

Two techniques are used by the atmospheric modeling community to establish the effect of regional emissions on global concentration distributions, namely tagging tracers of pollutant emissions (Liu and Mauzerall, 2005, 2007; Liu et al., 2005) and conducting sensitivity studies. In sensitivity studies, emissions of a pollutant from a given region are varied to examine the effects on downwind concentrations (Park et al., 2004; Heald et al., 2006; Chin et al., 2007; Koch et al., 2007b). The results using these two approaches can differ depending on the linearity of the chemical conversion of $\mathrm{SO}_{2}$ to sulfate between the source and receptor regions. In this study, we use a coupled tagging-sensitivity approach to quantify the S-R relationship and compare the difference between these two techniques. Our objectives are:

1. to determine the effect of potential future increases or decreases in $\mathrm{EA} \mathrm{SO}_{2}$ emissions on sulfate concentrations over downwind regions (Sect. 3);

2. to quantify the linearity of the S-R relationship between EA $\mathrm{SO}_{2}$ emissions and sulfate concentrations globally (Sects. 4 and 3)

3. to compare the source-receptor relationships obtained using tagging and sensitivity studies (Sect. 5). 

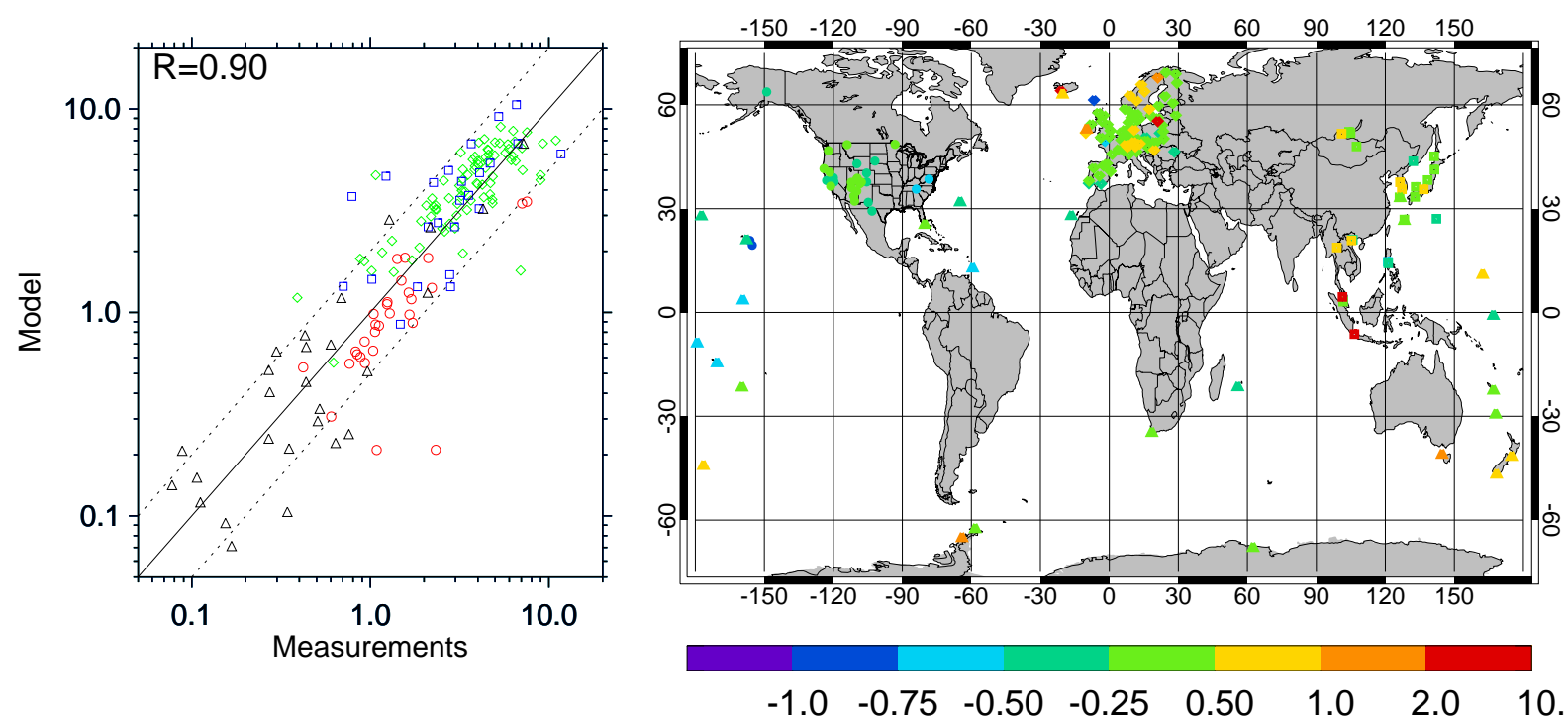

Fig. 2. Scatter plot (left panel) and the relative difference (i.e., (model-obs)/obs, right panel) between the simulated (MOZART2, early 1990s) and observed annual mean sulfate concentrations $\left(\mathrm{SO}_{4}{ }^{2-}\right.$; unit: $\left.\mu \mathrm{g} \mathrm{m}^{-3}\right)$. Observations are from RSMAS (1980s-1990s average, University of Miami, triangles), IMPROVE (1990-1992 average, circles), EMEP (1990-1992 average, diamonds), and EANET (2000-2004 average, squares).

\section{Methods}

We use the three-dimensional global chemical oxidantaerosol (fully coupled) transport model MOZART-2 (Model of Ozone and Related Tracers, version 2) (Horowitz et al., 2003) driven with NCEP/NCAR reanalysis meteorology to simulate inter-continental transport of sulfate aerosols. The model is configured with a T62 $\left(1.9^{\circ} \times 1.9^{\circ}\right)$ horizontal resolution and 28 hybrid vertical levels from the surface to $2.7 \mathrm{mb}$. Standard MOZART-2 emission inventories are used which represent global emissions in the early 1990s (Olivier, 1996; Horowitz et al., 2003). Table 1 summarizes the annual sulfur emissions from ten continental regions. The sulfur emissions from EA account for approximately $21 \%$ of the global emission total. Detailed descriptions of the model and model evaluation are provided by Horowitz et al. (2003, 2006), Tie et al. (2005) and Ginoux et al. (2006).

MOZART-2 simulates sulfate production including both gas phase oxidation of $\mathrm{SO}_{2}$ by $\mathrm{OH}$ radicals and aqueous phase oxidation of $\mathrm{SO}_{2}$ by $\mathrm{H}_{2} \mathrm{O}_{2}$ (Martin and Damschen, 1981) and $\mathrm{O}_{3}$ (Feichter et al., 1996). In addition, naturally produced dimethyl sulfide (DMS) is oxidized to $\mathrm{SO}_{2}$ by gasphase reactions with $\mathrm{OH}$ and $\mathrm{NO}_{3}$ radicals. Aqueous oxidation of $\mathrm{SO}_{2}$ to sulfate depends on cloud water content, cloud $\mathrm{pH}$, temperature, and abundance of oxidizing agents (namely $\mathrm{H}_{2} \mathrm{O}_{2}$ and $\mathrm{O}_{3}$ ). When clouds are present, MOZART-2 first predicts the $\mathrm{pH}$ values based on the mixing ratios of $\mathrm{SO}_{2}$, $\mathrm{CO}_{2}, \mathrm{HNO}_{3}$, sulfate, and $\mathrm{NH}_{3}$ (the contribution of organic acids to cloud acidity is not included in our calculation). It then uses the predicted $\mathrm{pH}$ and temperature to calculate the temperature dependent effective Henry's Law coefficients and aqueous reaction rate coefficients (Tie et al., 2005). When the cloud $\mathrm{pH}$ is below 5 , the reaction rate between $\mathrm{SO}_{2}$ and $\mathrm{H}_{2} \mathrm{O}_{2}$ is much faster than that between $\mathrm{SO}_{2}$ and $\mathrm{O}_{3}$ (Brasseur et al., 1999; Seinfeld and Pandis, 1998). Removal processes for sulfur species include both dry deposition and wet scavenging. The dry deposition velocities for $\mathrm{SO}_{2}$ are from Feichter et al. (1996) and are much faster over ocean $(0.8 \mathrm{~cm} / \mathrm{s})$ and land $(0.6 \mathrm{~cm} / \mathrm{s})$ than over snow $(0.2 \mathrm{~cm} / \mathrm{s})$. The dry deposition velocities for sulfate are $0.2 \mathrm{~cm} / \mathrm{s}$ (Feichter et al., 1996) over all surfaces. Wet deposition, including both in-cloud rainout and below cloud washout, is parameterized as a function of the effective Henry's law constant for each species (Horowitz et al., 2003). In the case of $\mathrm{SO}_{2}$, its dissolution in cloud droplets and precipitation is enhanced considerably over its physical solubility by acid dissociation and by rapid aqueous-phase oxidation from S(IV) to S(VI) (primarily by $\mathrm{H}_{2} \mathrm{O}_{2}$ ). To reflect this enhanced solubility, wet removal of $\mathrm{SO}_{2}$ is calculating using an increased effective Henry's law constant, equal to that of $\mathrm{H}_{2} \mathrm{O}_{2}$, as assumed by (Tie et al., 2001, 2005; Horowitz, 2006). For sulfate, the wet deposition rates are set to $20 \%$ of that for the highly soluble gas $\mathrm{HNO}_{3}$ (Horowitz, 2006).

In this study, we quantify S-R relationships using a coupled approach including tagged tracers and sensitivity simulations. We first conduct a baseline simulation with standard sulfur emissions. We then conduct five sensitivity simulations with anthropogenic sulfur emissions from EA reduced by $80 \%, 50 \%, 20 \%$, and increased by $20 \%$ and $50 \%$ relative to the base simulation. In all cases, we tag the anthropogenic emissions of $\mathrm{SO}_{2}$ from the ten continental regions including North America (NA), South America (SA), Europe (EU), the 


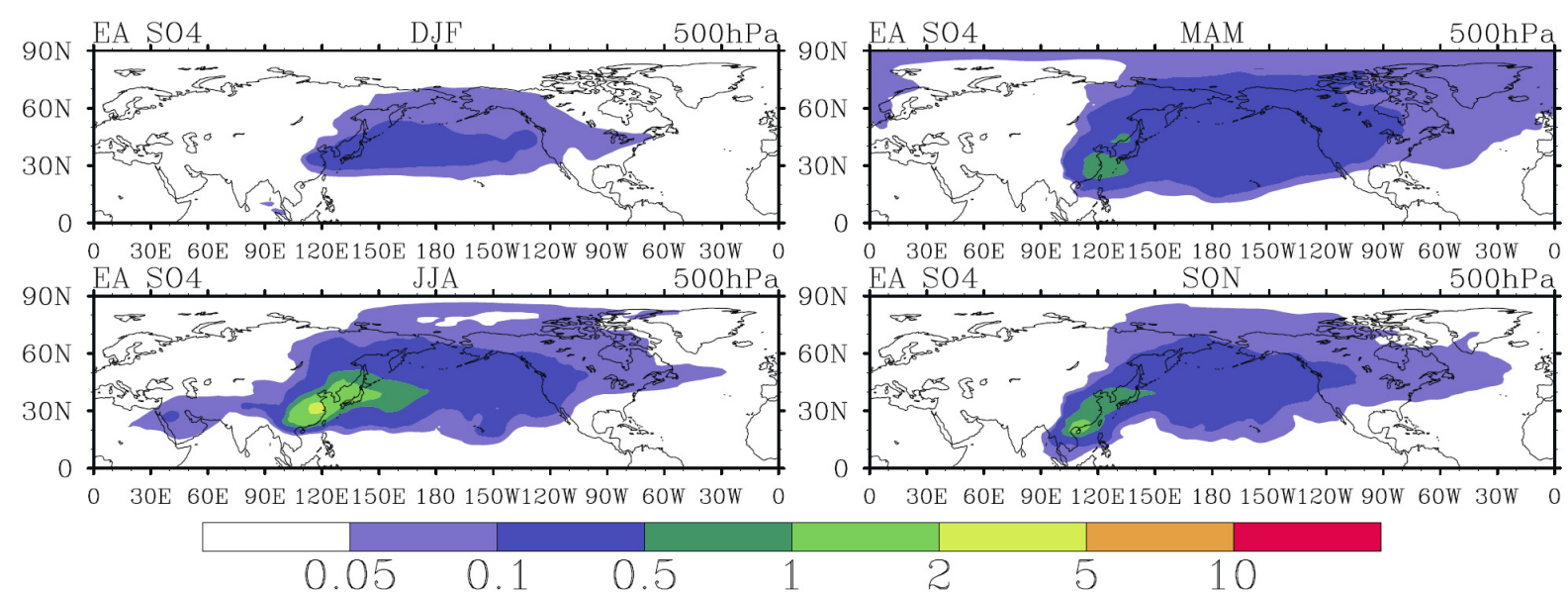

(a)

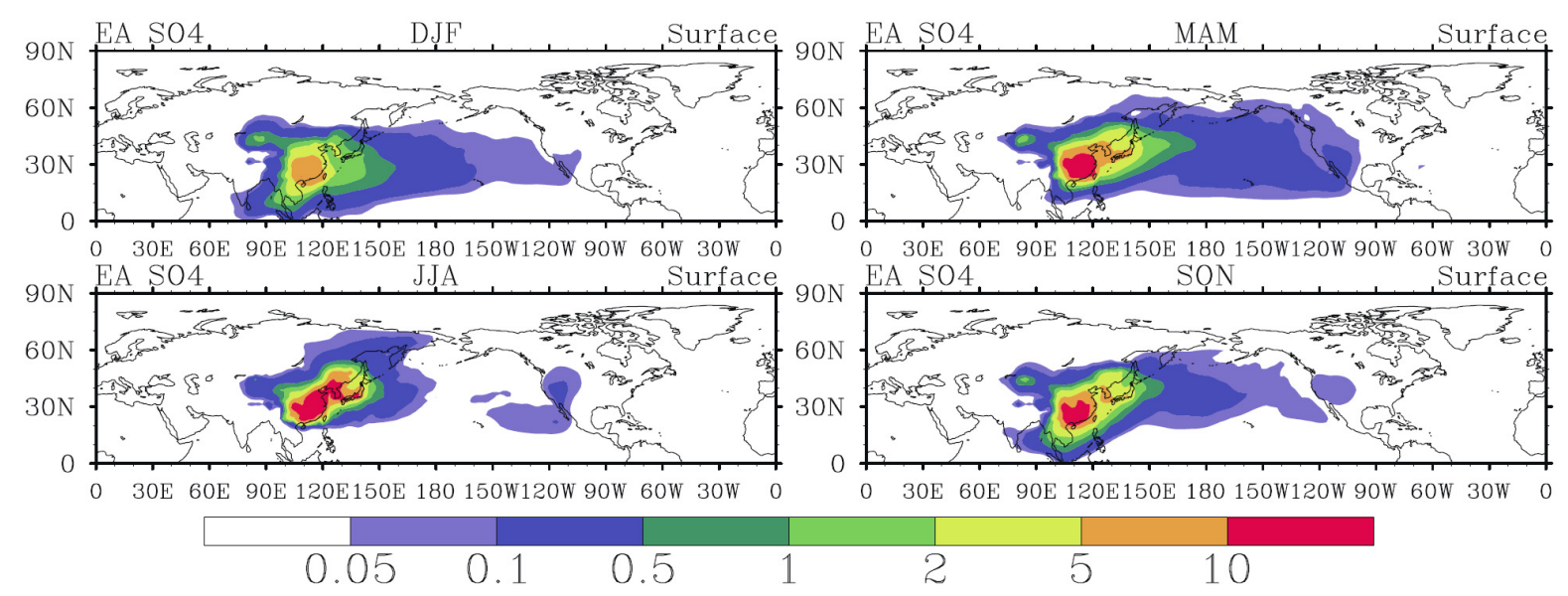

(b)

Fig. 3. Horizontal distribution of EA sulfate concentrations $\left(\mathrm{SO}_{4}\right.$; unit: $\mu \mathrm{g} \mathrm{m}^{-3}$ ) at (a) $500 \mathrm{hPa}$ and (b) the surface in DJF, MAM, JJA, and SON (letters correspond to the 12 months of the year).

Former Soviet Union (FSU, excluding part of Russia in the European domain), Africa (AF), Indian Subcontinent (IN), East Asia (EA), Southeast Asia (SE), Australia (AU), and the Middle East (ME) as shown in Fig. 1 and track their conversion to sulfate $\left(\mathrm{SO}_{4}^{2-}\right)$. Each simulation covers the 2-year period from 1990 to 1991 with the first year used for initialization.

Since this study uses meteorological inputs from the NCEP reanalysis (rather than MACCM-3 as in Horowitz et al., 2003), we then evaluate simulated aerosol concentrations by comparing the model results with various observations for sulfate, including the data collected by the Rosenstiel School of Marine and Atmospheric Science (RSMAS) at the University of Miami (Prospero, 1996) and by regional observation networks, namely the Interagency Monitoring of
Protected Visual Environments (IMPROVE) in the United States (http://vista.cira.colostate.edu/IMPROVE/), the Cooperative Program for Monitoring and Evaluation of the Longrange Transmission of Air Pollutants in Europe (EMEP: http://www.emep.int), and the East Asian Monitoring Network (EANET: http://www.eanet.cc). We average observations over 1980s-1990s for RSMAS data, over 1990 to 1992 for IMPROVE and EMEP data, and over 2000 to 2004 for EANET (however many EANET observation stations did not begin to report data until 2003). Figure 2 compares the MOZART-2 simulated sulfate concentrations with global observation networks. The MOZART-2 results are generally in good agreement with observations, with annual mean sulfate concentrations within a factor of 2 of observations at $80 \%$ of the global stations considered. In addition, the model tends to 


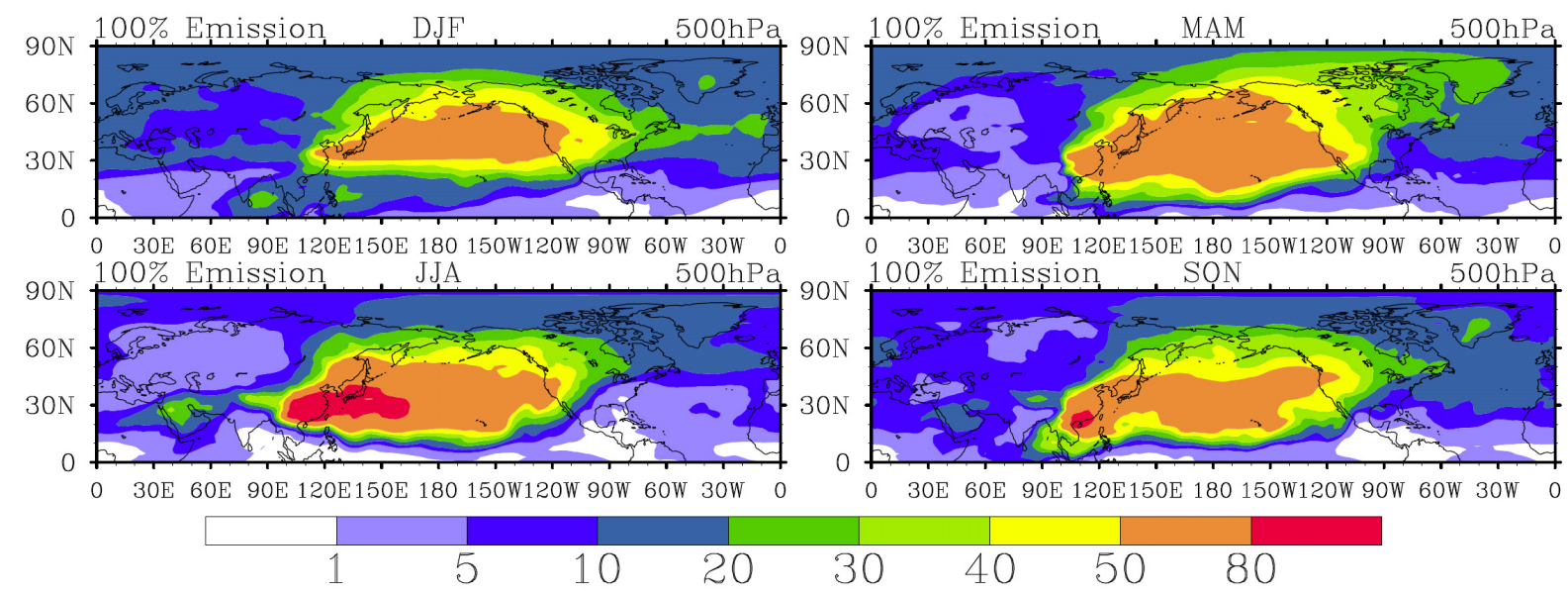

(a)

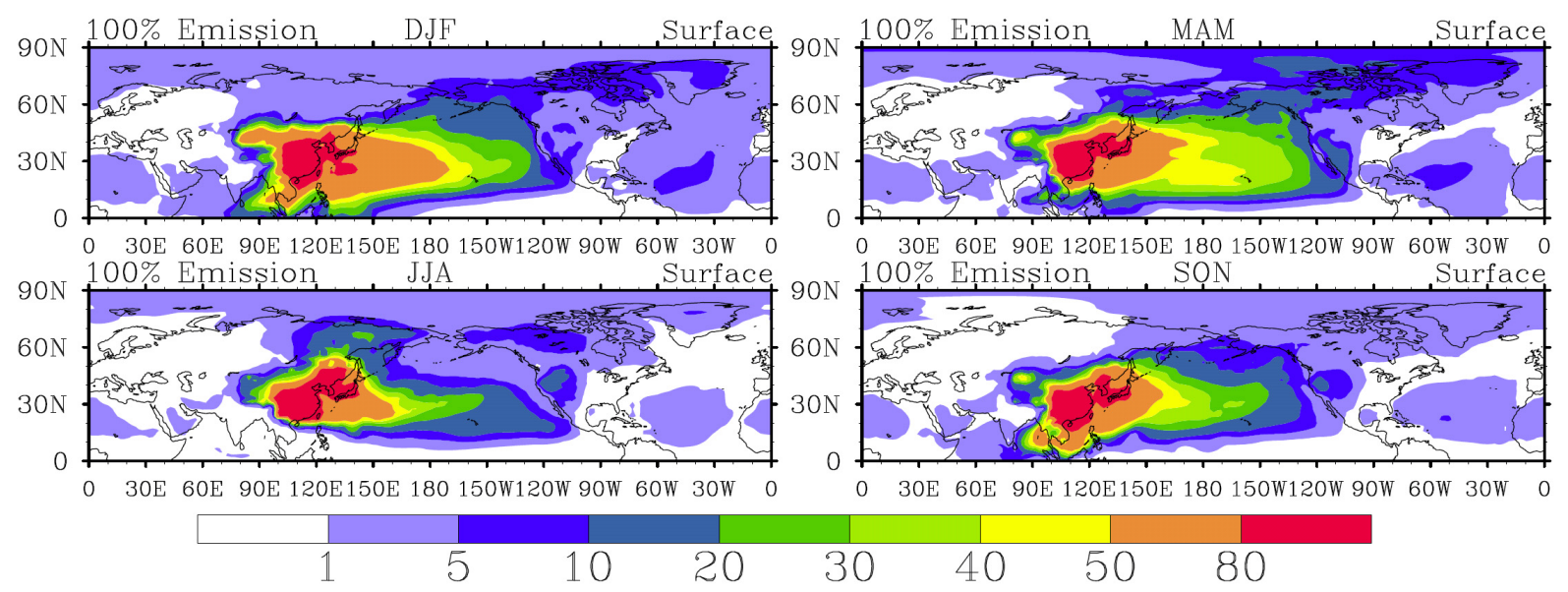

(b)

Fig. 4. Percent contribution of EA sulfate to total sulfate concentrations (using standard emissions) at (a) $500 \mathrm{hPa}$ and (b) the surface in the same seasons as in Fig. 3.

underestimate sulfate concentrations over the Eastern US by nearly $25-50 \%$. While the model shows little mean bias with respect to the EANET observations (from the early 2000s), it is likely that the model would overestimate sulfate concentrations over EA during the early 1990s (the period for which our emissions were estimated) because $\mathrm{SO}_{2}$ emissions from East Asia are estimate to have increased between the early 1990s and the early 2000s (Klimont et al., 2001).

\section{Global contribution of sulfate aerosol from EA}

The annual average simulated surface concentrations of EA sulfate $\left(\mathrm{SO}_{4}^{2-}\right)$ range from more than $10 \mu \mathrm{g} \mathrm{m}^{-3}$ over EA to less than $0.2 \mu \mathrm{g} \mathrm{m}^{-3}$ over the Western US (Fig. 3). These values are comparable to those obtained by other studies which use a sensitivity approach to estimate the contribution of Asian sulfate to the Western US (Park et al., 2004; Heald et al., 2006; Chin et al., 2007). Vertical lifting by convection and frontal activities (e.g., warm conveyor belts) followed by rapid transport in mid-latitude westerlies (or jet stream) are the main mechanisms for transporting EA air pollution to the North Pacific and North America (Kritz et al., 1990; Stohl, 2001; Stohl et al., 2002; Liu et al., 2003; Liu et al., 2005). The contribution of EA to surface sulfate over the Western US is highest in Spring (MAM) (up to $0.15 \mu \mathrm{g} / \mathrm{m}^{3}$ ) and lowest in Winter (DJF) $\left(<0.06 \mu \mathrm{g} / \mathrm{m}^{3}\right)$. In our earlier work (Liu et al., 2005; Liu and Mauzerall, 2005), we found that transPacific transport of an idealized tracer (with a fixed first-order 


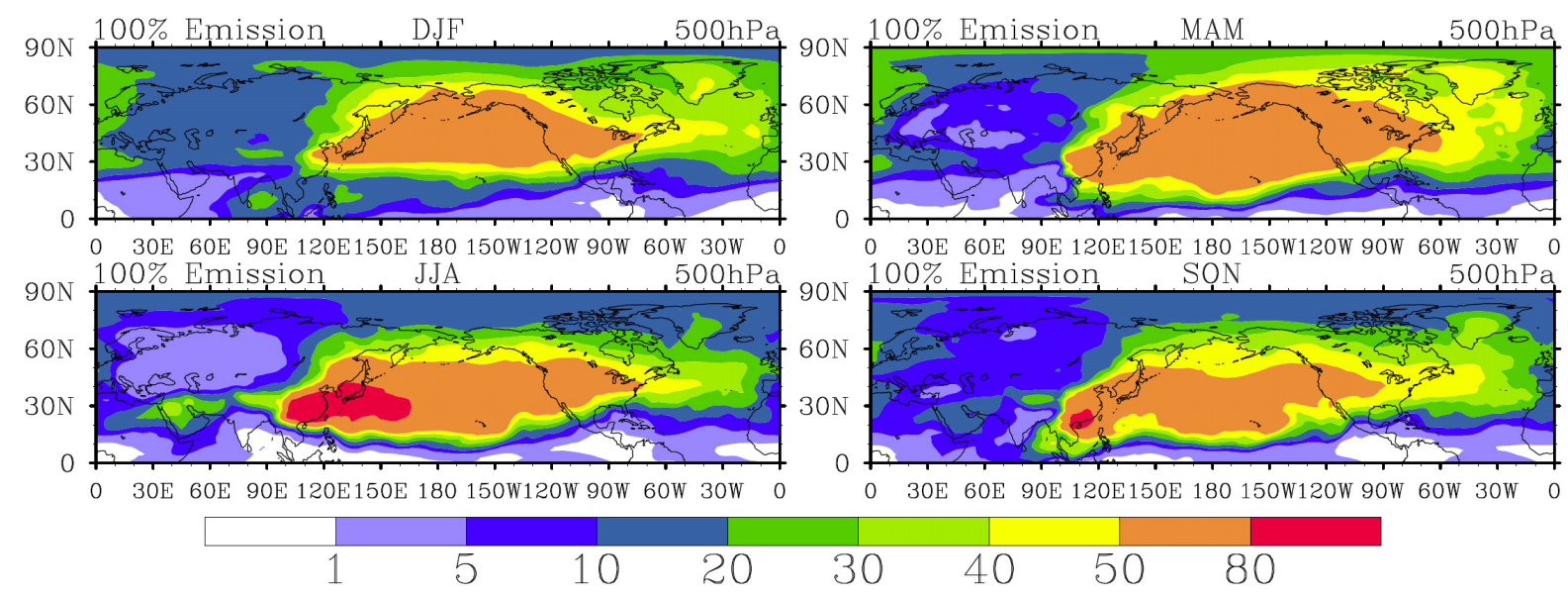

(a)
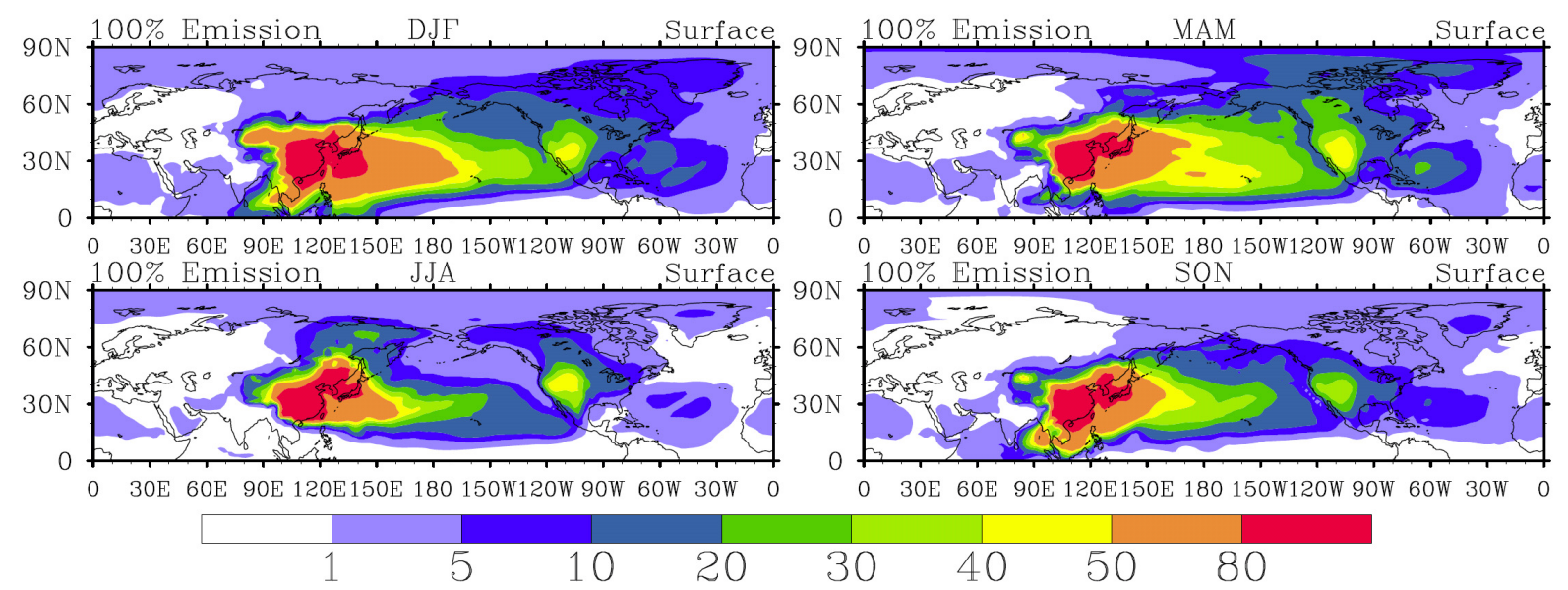

(b)

Fig. 5. Same as Fig. 4, but percent contribution of EA sulfate to North American (NA) background sulfate (Note: NA background sulfate is the difference between total sulfate concentrations and sulfate originating from anthropogenic sources in NA).

decay lifetime of 2 weeks) to be strongest in winter-spring and weakest in summer. The results here differ from those of our earlier study because sulfate production is highly dependent on the abundance of oxidants, which have different seasonal variation than trans-Pacific transport. Comparing Figs. $3 a$ and $b$, in summer the transport of EA sulfate to the Central Pacific in summer is weak at the surface but relatively strong at $500 \mathrm{hPa}$ where strong westerlies prevail. The summer high EA sulfate concentration over the Western US is the net result of a series of processes, including stronger convective transport over EA, faster sulfate production, faster wet removal, slower surface transport, and stronger subsidence (within summer highs) over the Western US in summer than in winter. Most recent field work examining transPacific transport (e.g. the 2002 Intercontinental Transport and Chemical Transformation campaign) and modeling research (e.g. Heald et al., 2006) has focused on spring. Our finding suggests that additional investigation of EA influence on sulfate concentrations over the Western US in summer and fall may be worthwhile.

The fractional contribution of sulfate concentrations from EA in the base simulation during each season is shown in Fig. 4. From west to east across the North Pacific, EA sulfate contributes from $80 \%$ to $20 \%$ of total sulfate at the surface, but contributes at least $50 \%$ at $500 \mathrm{hPa}$. This indicates that EA sulfate is the dominant source of sulfate over the Pacific Ocean, particularly in the free troposphere. Sulfate aerosols directly scatter solar radiation and increase the albedo of clouds. Thus, they cool the Pacific air mass which could influence regional climate over the Western US. Investiga- 


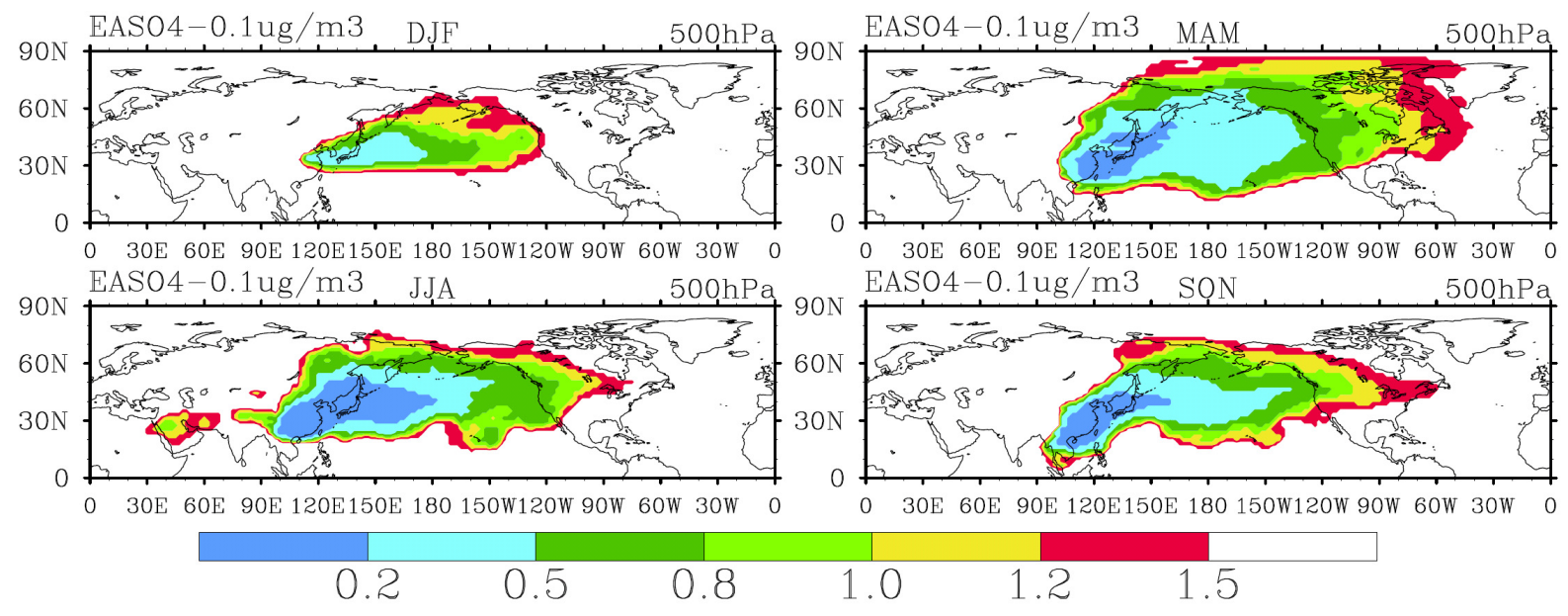

(a)
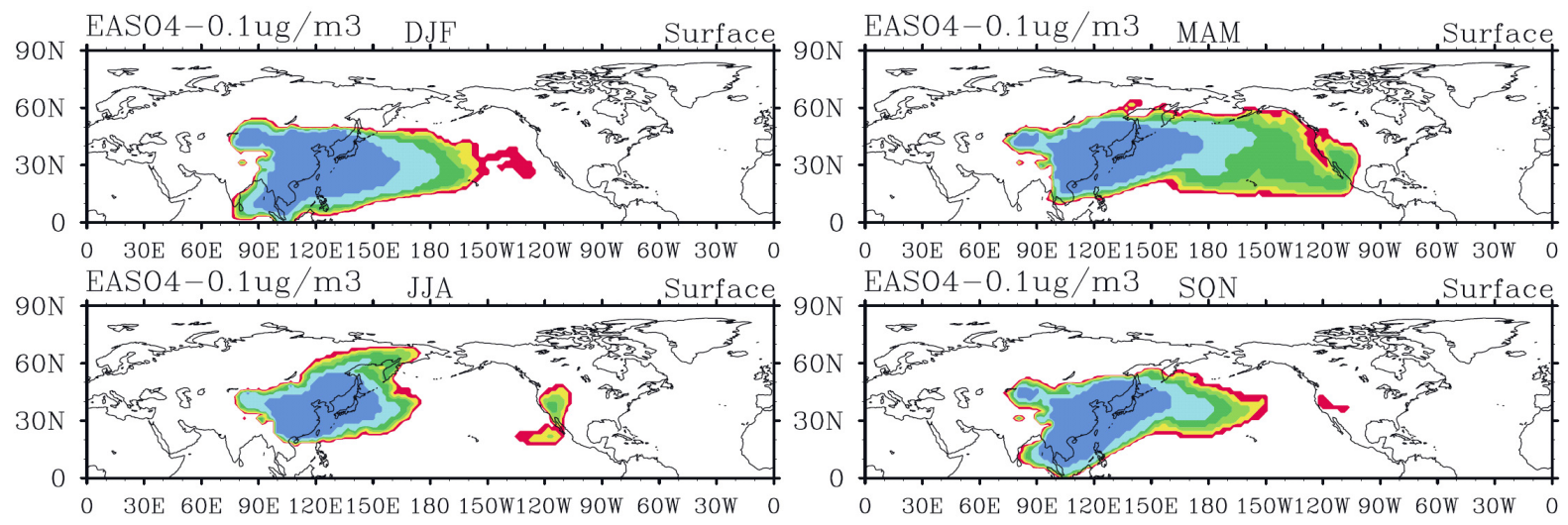

0.2

0.5

0.8

1.0

1.2

1.5

(b)

Fig. 6. Areas where at least $0.1 \mu \mathrm{g} \mathrm{m}^{-3}$ of sulfate originates from EA (AEA0.1) at (a) $500 \mathrm{~h} \mathrm{~Pa} \mathrm{(b)} \mathrm{the} \mathrm{surface} \mathrm{over} \mathrm{the} \mathrm{same} \mathrm{seasons} \mathrm{as} \mathrm{in}$ Fig. 3 when EA sulfur emissions are 0.2, 0.5, 0.8, 1.0, 1.2 and 1.5 times standard EA emissions (indicated by colors).

tion into linkages between changing EA sulfate concentrations over the North Pacific and their impact on US climate would be valuable (e.g., Levy et al., 2008). Over the surface of the US, EA sulfate contributes more than $10 \%$ of total sulfate over the Western US in MAM and JJA, but its influence is negligible over the Eastern US $(<1 \%)$ due to the dominance of domestic sources (Fig. 4).

Figure 5 shows the fractional contribution of EA to background sulfate over North America (i.e., total sulfate concentrations minus sulfate from anthropogenic sources in NA). At the surface, EA sulfate accounts for 30\%-50\% and 10\%$20 \%$ of background sulfate over the Western and Eastern US, respectively. Due to the differences in model use, emission inventories and meteorological input, as well as the definition of "background sulfate" and "East Asian sources", our result differs slightly from that of Park et al. (2004), who find that total Asian pollution accounts for $30 \%$ of background sulfate over both Western and Eastern US, and Chin et al. (2007), who find that Asian pollution accounts for $\sim 40 \%$ and $\sim 30 \%$ of background sulfate over the Western and Eastern US, respectively. At $500 \mathrm{hPa}$, EA sulfate accounts for more than $50 \%$ of background sulfate over the US (Fig. 5a).

With standard EA $\mathrm{SO}_{2}$ emissions, EA sulfate concentrations can exceed $0.1 \mu \mathrm{g} \mathrm{m}^{-3}\left(\mathrm{~A}_{\mathrm{EA} 0.1}\right)$ over the Western United States at $500 \mathrm{hPa}$ (Fig. 3a) and even at the surface (Fig. 3b), particularly in MAM and JJA (for comparison, 


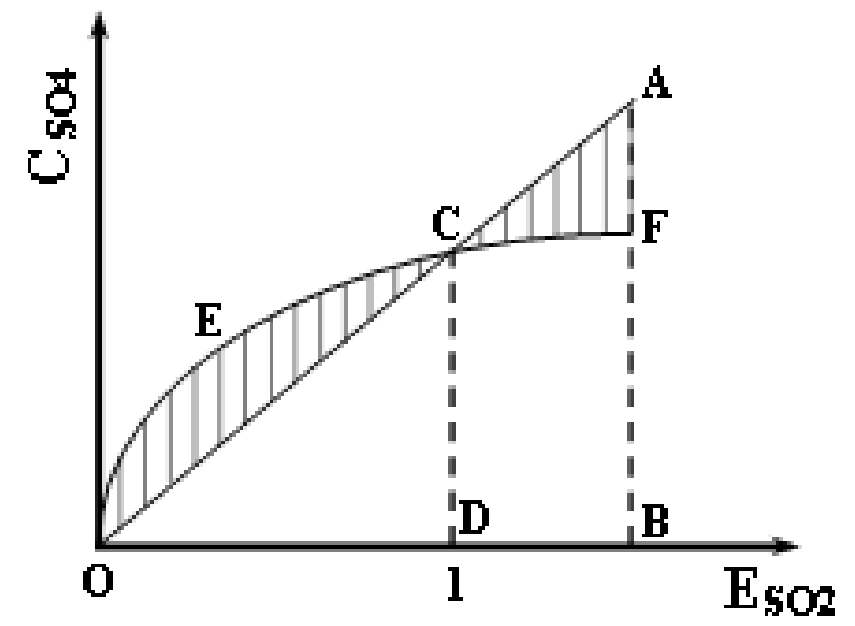

Fig. 7. Schematic of the linearity of S-R relationships between the $\mathrm{SO}_{2}$ emission scale factor $\left(\mathrm{E}_{\mathrm{SO}_{2}}\right.$, the $\mathrm{SO}_{2}$ emissions in each sensitivity run scaled to the baseline emissions) and the sulfate concentration scale factor $\left(\mathrm{C}_{\mathrm{SO}_{4}}\right.$, the average sulfate concentration in each sensitivity run scaled to the baseline concentrations). The straight line OA shows the idealized perfect linear dependence of $\mathrm{C}_{\mathrm{SO}_{4}}$ on $\mathrm{E}_{\mathrm{SO}_{2}}$, when $\mathrm{E}_{\mathrm{SO}_{2}}$ varies between $\mathrm{O}$ and $\mathrm{B}$. The convex curve $\mathrm{OECF}$ shows the actual relationship between $\mathrm{C}_{\mathrm{SO}_{4}}$ and $\mathrm{E}_{\mathrm{SO}_{2}}$. The linearity index L is defined by Eq. (1) in Sect. 4 (Note: "1" here indicates standard emissions, and "O" indicates zero emissions or concentration).

the US EPA's annual average $\mathrm{PM}_{2.5}$ air quality standard is $15 \mu \mathrm{g} \mathrm{m}^{-3}$ ). Figure 6 illustrates how the $\mathrm{A}_{\mathrm{EA} 0.1}$ changes with increases/decreases in $\mathrm{EA} \mathrm{SO}_{2}$ emissions. At the surface, the spatial extent of $\mathrm{A}_{\mathrm{EA} 0.1}$ is constrained to the North Pacific and is sensitive to EA emissions between $20 \%$ and $80 \%$ of standard EA emissions. Therefore, a decrease of EA $\mathrm{SO}_{2}$ emissions will significantly decrease the spatial extent of EA sulfate over the surface of the North Pacific, but an increase in emissions will not significantly increase the horizontal extent of EA sulfate at the surface. The eastern boundary of $\mathrm{A}_{\mathrm{EA} 0.1}$ reaches the Western US at the surface only when $\mathrm{EA} \mathrm{SO}_{2}$ emissions increase by more than $50 \%$ beyond the standard emissions (especially in MAM and JJA). Since most EA sulfate is efficiently removed from the lower troposphere by wet and dry deposition during transport over the North Pacific, further increases in EA sulfur emissions will not significantly increase the surface concentrations and deposition of sulfate over the US. These results are supported by the measurements reported in Jaffe et al. (2005) and Prospero et al. (2003) which indicate that samples from Midway Island in the North Pacific are significantly more influenced by Asian industrial sources of sulfur than measurements at Crater Lake in Oregon. At $500 \mathrm{hPa}$ (Fig. 6a), where sulfate removal is slower and oxidants are relatively abundant, increasing EA emissions cause the eastern boundary of $\mathrm{A}_{\mathrm{EA} 0.1}$ to expand from the Western Pacific (20\% EA emissions) to the Eastern US (150\% EA emissions), particularly in MAM and SON. In addition, the spatial extent of $\mathrm{A}_{\mathrm{EA} 0.1}$ at $500 \mathrm{hPa}$ is approximately twice as large as that at the surface in JJA. These findings suggest that future changes in EA sulfur emissions may cause little change in sulfate induced health effects over the US, but may cause a significant change in the sulfate related climate impact over the North Pacific and the Western US.

\section{Linearity of the S-R relationship}

The linearity between $\mathrm{SO}_{2}$ emissions and sulfate concentrations is of importance to both policymakers interested in reducing the impacts of sulfate exposure and scientists eager to understand the oxidation rate of $\mathrm{SO}_{2}$ which depends on the concentrations of $\mathrm{H}_{2} \mathrm{O}_{2}, \mathrm{OH}$, and $\mathrm{O}_{3}$. Here we quantitatively investigate the linearity of the response of sulfate concentrations to changes in $\mathrm{SO}_{2}$ emissions. As $\mathrm{SO}_{2}$ emissions increase, non-linearity may arise as oxidants are consumed increasingly quickly hence reducing the production efficiency of sulfate (Berglen et al., 2004; Koch et al., 2007b)

Figure 7 shows the $\mathrm{S}-\mathrm{R}$ relationship between $\mathrm{SO}_{2}$ emissions (scaled to the baseline $\mathrm{SO}_{2}$ emissions) and sulfate concentrations (scaled to the baseline sulfate concentrations). When the S-R relationship is linear, sulfate concentrations increase proportionally with the increase in $\mathrm{SO}_{2}$ emissions (following line $\mathrm{OA}$ ). However, if the increase in $\mathrm{SO}_{2}$ emissions decreases the availability of oxidants, the S-R relationship will follow the OECF curve, which is non-linear. The change of slope along OECF indicates the change in oxidizing capacity of the atmosphere. To quantify the linearity of the oxidation process, we define a cumulative linearity index (L) which indicates the percentage departure from linearity:

$\mathrm{L}=\frac{\mathrm{S}_{\mathrm{OEC}}+\mathrm{S}_{\mathrm{CFA}}}{\mathrm{S}_{\mathrm{OAB}}} \times 100 \%$

$S_{\mathrm{OAB}}$ is the area of the triangle $\mathrm{OAB}$ associated with a linear S-R relationship (Fig. 7$) ; S_{\mathrm{OEC}}\left(S_{\mathrm{OECD}}-S_{\mathrm{OCD}}\right)$ and $S_{\mathrm{CFA}}$ $\left(S_{\mathrm{CABD}}-S_{\mathrm{CFBD}}\right)$ are the shaded areas in Fig. 7 , indicating departure from linearity. When $\mathrm{L}=0$, the $\mathrm{S}-\mathrm{R}$ relationship is perfectly linear and the atmospheric oxidation power for $\mathrm{SO}_{2}$ is unchanged. A larger L-value implies stronger nonlinearity, resulting from lower oxidant availability. In reality, the S-R relationship is rarely perfectly linear. This is because sulfate is a secondary aerosol and an increase in $\mathrm{SO}_{2}$ emissions will influence both oxidation power and photochemistry over both source and downwind regions. By comparing the shape of the OECF curve (in Fig. 7) to the L-index in different locations, we find that when $\mathrm{L}<5 \%$, the $\mathrm{S}-\mathrm{R}$ relationship is very close to linear. In contrast, when $\mathrm{L}>10 \%$, a non-linear S-R relationship can be easily identified (see plots in the supplementary material http://www.atmos-chem-phys. net/8/3721/2008/acp-8-3721-2008-supplement.pdf). 


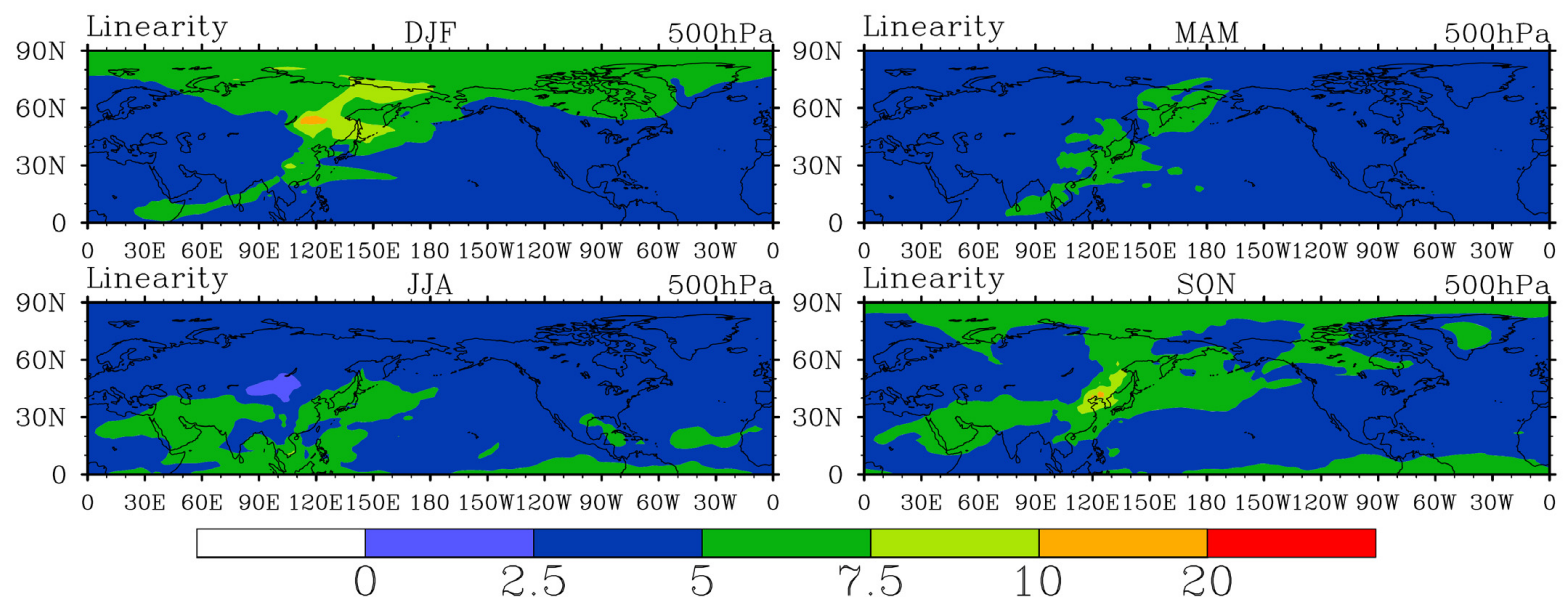

(a)

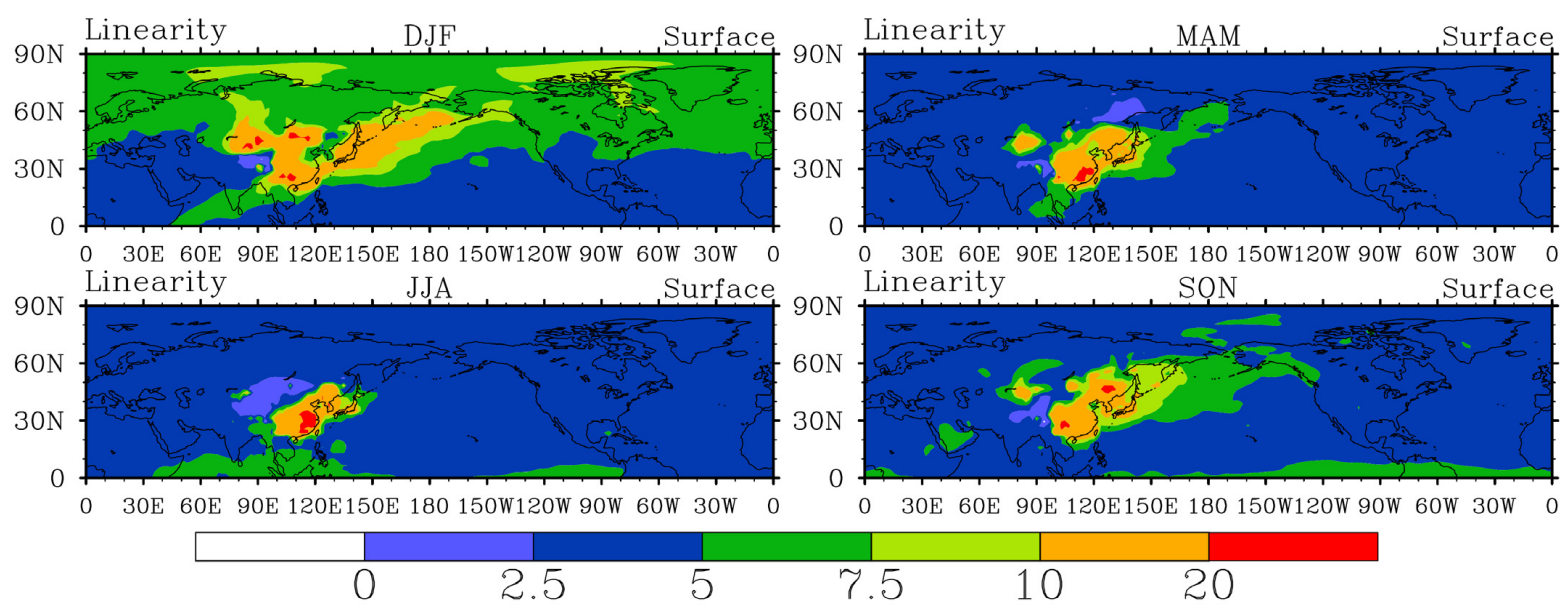

(b)

Fig. 8. Distribution of the Linearity Index (L) for the S-R relationship between $\mathrm{EA} \mathrm{SO}_{2}$ emissions and EA sulfate concentrations over the northern hemisphere (based on Eq. (1) where low numbers indicate approximate linearity; EA sulfur emissions range from 0 to 1.5 times the standard emissions) at (a) $500 \mathrm{hPa}$ and (b) the surface. Seasons are the same as in Fig. 3.

Figure 8 shows the distribution of $\mathrm{L}_{0-1.5}$ (i.e., the linearity index obtained by varying EA emissions from 0 to 1.5 times the standard EA sulfur emissions) for the S-R relationship between $\mathrm{EA} \mathrm{SO}_{2}$ emissions and EA sulfate concentrations in the Northern Hemisphere. In regions where $\mathrm{SO}_{2}$ emissions are large, oxidant limitation results in incomplete conversion to sulfate, limiting the increase in sulfate concentrations as $\mathrm{SO}_{2}$ emissions are increased. This results in the convex curve seen in Fig. 7 and a positive value for L. Over EA, high $\mathrm{L}_{0-1.5}$-values ( $>10 \%$ and more than $20 \%$ over Southeastern China) are found at the surface in all seasons, indicating a persistent non-linear S-R relationship over EA and significant variations of atmospheric oxidation power for $\mathrm{SO}_{2}$. For example, in this study a $50 \%$ change (either increase or de- crease) of EA sulfur emissions is associated with 5-10\% (1$2 \%), 2-5 \%(0.5-2)$, and $1-2 \%(0.5-1 \%)$ change in surface $\mathrm{H}_{2} \mathrm{O}_{2}, \mathrm{OH}$, and $\mathrm{O}_{3}$ concentrations over EA (Eastern Pacific), with the largest percentage changes occurring in winter for $\mathrm{OH}$ and $\mathrm{O}_{3}$ and in summer for $\mathrm{H}_{2} \mathrm{O}_{2}$ (plots are given in the supplementary material http://www.atmos-chem-phys.net/8/ 3721/2008/acp-8-3721-2008-supplement.pdf). As shown in Fig. $8 \mathrm{~b}$, over the Western Pacific the $\mathrm{L}_{0-1.5}$-values in JJA are low $(<5 \%)$, indicating a higher atmospheric oxidation power for $\mathrm{SO}_{2}$ than in other seasons. In addition, over the Eastern Pacific and North America, the $\mathrm{L}_{0-1.5}$-values are low $(<5 \%)$ in most seasons except winter (at high latitudes where oxidant levels are low). At $500 \mathrm{hPa}$ (Fig. 8a), the $\mathrm{L}_{0-1.5}$-values are relatively low even over the EA source region. There- 


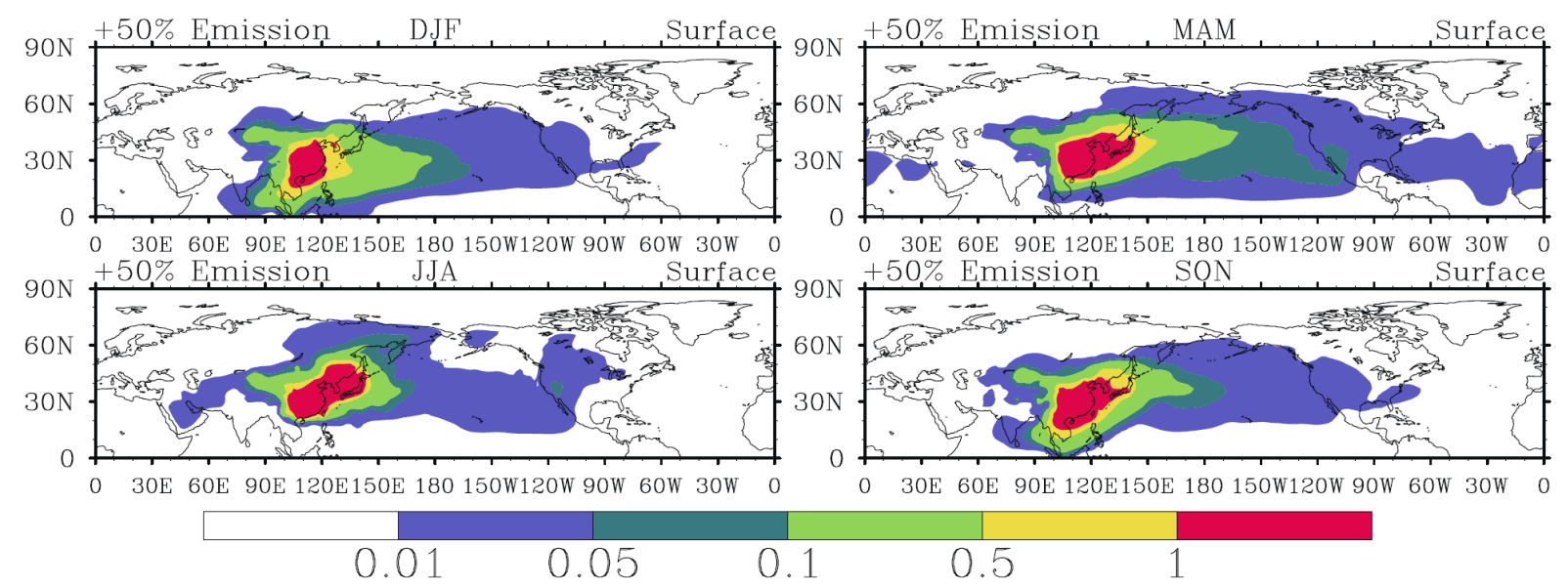

(a)

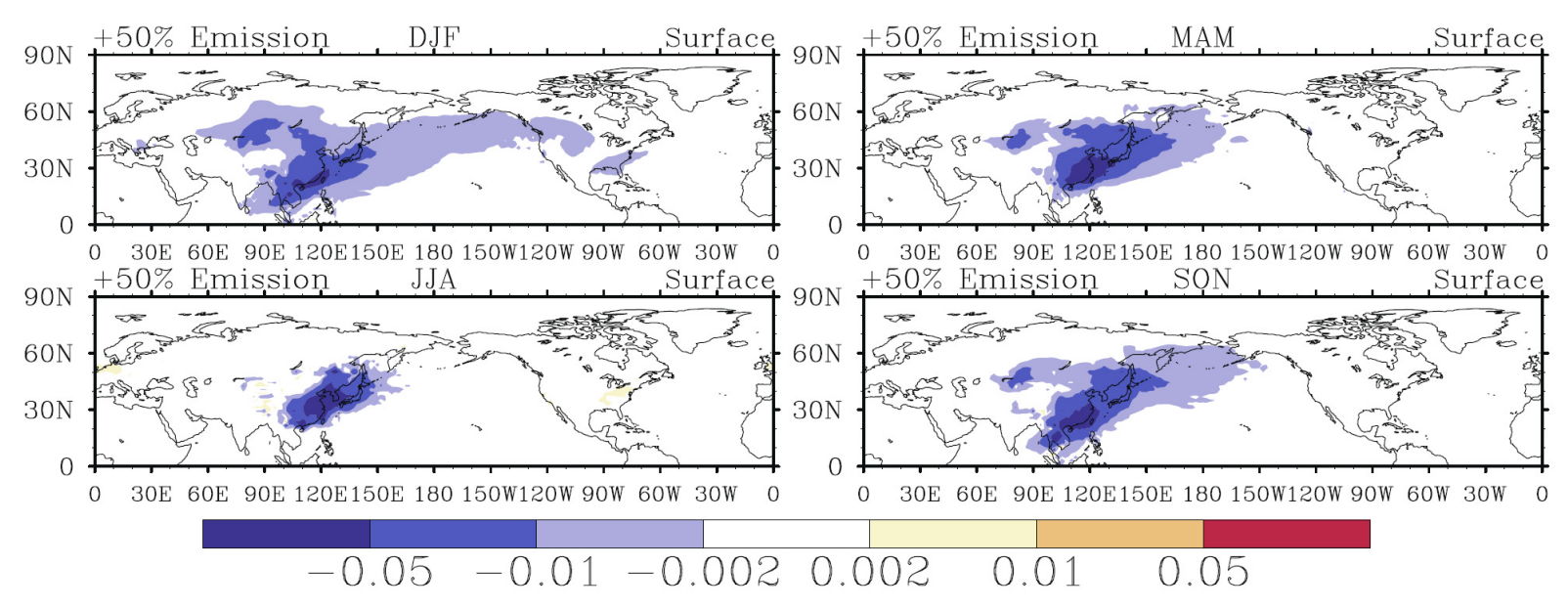

(b)

Fig. 9. Direct (a) and indirect (b) effects on surface sulfate concentrations (unit: $\mu \mathrm{g} \mathrm{m}^{-3}$ ) from $50 \%$ increase of $\mathrm{EA} \mathrm{SO}_{2}$ emissions (note: different color scales). Direct effects refer to changes in sulfate produced from EA emissions, while indirect effects refer to changes in sulfate concentrations produced from pollutant emissions in other regions.

fore, the S-R relationships between $\mathrm{EA} \mathrm{SO}_{2}$ emissions and EA sulfate concentrations are close to linear everywhere except at the surface over EA.

\section{Direct and indirect effects of the change in $\mathrm{EA} \mathrm{SO}_{2}$ emissions}

Changing $\mathrm{SO}_{2}$ emissions in EA leads to a direct change in EA sulfate and an indirect change in sulfate from other sources, which cannot be distinguished using sensitivity studies alone. Usually sensitivity studies represent the total change in sulfate concentrations between a perturbation run in which $\mathrm{EA} \mathrm{SO} \mathrm{SO}_{2}$ emissions are changed and the base run. Using our tagged regional sulfur tracers we identify a direct change in EA sulfate concentrations (due to production and transport of sulfate from $\mathrm{SO}_{2}$ emitted in EA). We also identify an indirect effect: the response of non-EA sulfate (i.e., the sulfate produced and transported from $\mathrm{SO}_{2}$ emitted in regions other than $\mathrm{EA})$ to the change in $\mathrm{EA} \mathrm{SO}_{2}$ emissions. The negative indirect effect results from a reduction in the concentration of oxidants (particularly $\mathrm{H}_{2} \mathrm{O}_{2}$ ) which in turn slows down the oxidation of non-EA $\mathrm{SO}_{2}$.

Figure 9 shows the direct and indirect changes in surface sulfate concentrations that result from increasing $\mathrm{EA} \mathrm{SO}_{2}$ emissions by $50 \%$. Raising $\mathrm{EA} \mathrm{SO}_{2}$ emissions has the direct effect of increasing EA sulfate concentrations across the Pacific Ocean (Fig. 6a) and the indirect effect of decreasing non-EA sulfate concentrations over East Asia (Fig. 6b). As 
shown in Fig. 9, the direct and indirect effects are both largest over the source region and diminish downwind. However, the direct effect exceeds the indirect effect by more than a factor of 10 over the source region and North Pacific (particularly between $20^{\circ} \mathrm{N}-50^{\circ} \mathrm{N}$ ). Therefore, very similar trans-Pacific EA sulfate $\mathrm{S}-\mathrm{R}$ relationships are obtained using tagging and sensitivity techniques. At $500 \mathrm{hPa}$, the magnitudes of the direct effect are $0.1-0.5 \mu \mathrm{g} \mathrm{m}^{-3}, 0.05-0.1 \mu \mathrm{g} \mathrm{m}^{-3}$, and less than $0.05 \mu \mathrm{g} \mathrm{m}^{-3}$ over the Western Pacific, Eastern Pacific and the United States (not shown). The indirect effect is negligible $\left(<0.01 \mu \mathrm{g} \mathrm{m}^{-3}\right)$.

\section{Conclusions}

We analyze the source-receptor relationships between sulfur emissions from East Asia and the resulting sulfate concentrations over both source and downwind regions using the global oxidant-aerosol model (MOZART-2). We conduct a base simulation and five sensitivity simulations in which EA sulfur emissions are varied. In each simulation, we tag sulfur species from EA and other continental regions.

We find that the concentrations of EA sulfate in surface air over the Western US (resulting from trans-Pacific transport) is highest in MAM and JJA $\left(>0.1 \mu \mathrm{g} \mathrm{m}^{-3}\right)$ and is lowest in DJF $\left(<0.06 \mu \mathrm{g} \mathrm{m}^{-3}\right)$. This spring (summer) maximum in EA sulfate over the US is caused by the efficient production and frontal (convective) lifting of sulfate aerosols over the EA source region followed by relatively rapid transPacific transport in the free troposphere. Our findings indicate that for environmental policy (e.g., risk to human health due to sulfate's contribution to $\mathrm{PM}_{2.5}$ ), summertime transPacific transport of East Asian sulfate to the Western US is as important as that in spring.

We find that present-day EA $\mathrm{SO}_{2}$ emissions account for at least $50 \%$ (20\%) of total sulfate concentrations over the North Pacific at $500 \mathrm{hPa}$ (at the surface). EA SO $\mathrm{SO}_{2}$ emissions account for approximately $30-50 \%$ and $10-20 \%$ of background sulfate (defined here as total sulfate minus sulfate from NA anthropogenic sources) at the surface over the Western and Eastern US, respectively. At $500 \mathrm{hPa}$, the EA $\mathrm{SO}_{2}$ emissions account for at least $50 \%$ of background sulfate over even the Eastern US.

Using a series of sensitivity simulations, we compare the areas over which EA sulfate concentrations are at least $0.1 \mu \mathrm{g} \mathrm{m}^{-3}\left(\mathrm{~A}_{\mathrm{EA} 0.1}\right)$. We find that reducing EA SO $\mathrm{SO}_{2}$ emissions will significantly decrease the spatial extent of $A_{E A 0.1}$ over the North Pacific at both the surface and $500 \mathrm{hPa}$, but the spatial extent is insensitive to emission increases except for spring and fall at $500 \mathrm{hPa}$. In addition, the spatial extent of $\mathrm{A}_{\mathrm{EA} 0.1}$ at $500 \mathrm{hPa}$ is approximately twice as broad as at the surface in JJA, indicating the efficient trans-Pacific transport of EA sulfate in the free troposphere in summer. These findings suggest that future changes in EA sulfur emission may cause little change in the sulfate induced health impact over downwind continents but might significantly influence the sulfate related climate change over the North Pacific and the Western US.

We quantify the degree of linearity in the S-R relationship between $\mathrm{EA} \mathrm{SO}_{2}$ emissions and EA sulfate concentrations in the northern hemisphere by defining a linearity index. We find that EA sulfate concentrations respond nearly linearly (within 5\%) to changes in $\mathrm{EA} \mathrm{SO}_{2}$ emissions everywhere except over the EA source region (where non-linearities exceed $10 \%$, particularly at the surface during winter). Sulfate concentrations over EA increase proportionately less than the EA sulfur emissions because the conversion of $\mathrm{SO}_{2}$ to sulfate reduces the availability of atmospheric oxidants (particularly $\mathrm{H}_{2} \mathrm{O}_{2}$ ), which in turn slows down the production rate for sulfate aerosol. However, even under low-oxidant conditions, conversion to sulfate occurs more quickly than transport to other continental regions.

We compare the direct effect (i.e., the change in sulfate produced from $\mathrm{EA} \mathrm{SO}_{2}$ emissions) and indirect effect (i.e., response of non-EA sulfate) of changing $\mathrm{EA} \mathrm{SO}_{2}$ emissions. We find that raising $\mathrm{EA} \mathrm{SO}_{2}$ emissions leads to a positive direct effect and a negative indirect effect on sulfate concentrations, particularly over the source region. However, the magnitude of the direct effect is more than 10 times larger than the indirect effect over the mid-latitude Pacific. We therefore conclude that the tagging and sensitivity techniques will produce nearly identical estimates of the source-receptor relationship of trans-Pacific transport of sulfate aerosols.

Acknowledgements. We thank the Geophysical Fluid Dynamics Laboratory for computational resources. We are pleased to acknowledge funding from Princeton University and a NASA New Investigator Program grant to D. Mauzerall.

Edited by: F. J. Dentener

\section{References}

Berglen, T. F., Berntsen, T. K., Isaksen, I. S. A., and Sundet, J. K.: A global model of the coupled sulfur/oxidant chemistry in the troposphere: the sulfur cycle, J. Geophys. Res.-Atmos., 109, D19310, doi:10.1029/2003JD003948, 2004.

Brasseur, G. P., Orlando, J. J., Tyndall, G. S., and National Center for Atmospheric Research (US): Atmospheric chemistry and global change, Topics in environmental chemistry, Oxford University Press, New York, USA, 18, 654 pp., 1999.

Carlson, C., Burtraw, D., Cropper, M., and Palmer, K. L.: Sulfur dioxide control by electric utilities: what are the gains from trade?, J. Politic. Econ., 108, 1292-1326, 2000.

Chin, M., Diehl, T., Ginoux, P., and Malm, W.: Intercontinental transport of pollution and dust aerosols: implications for regional air quality, Atmos. Chem. Phys., 7, 5501-5517, 2007, http://www.atmos-chem-phys.net/7/5501/2007/.

Conrad, K. and Kohn, R. E.: The US market for $\mathrm{SO}_{2}$ permits: policy implications of the low price and trading volume, Energy Policy, 24, 1051-1059, 1996. 
Dutkiewicz, V. A., Das, M., and Husain, L.: The relationship between regional $\mathrm{SO}_{2}$ emissions and downwind aerosol sulfate concentrations in the Northeastern US, Atmos. Environ., 34, 1821-1832, 2000.

Feichter, J., Kjellstrom, E., Rodhe, H., Dentener, F., Lelieveld, J., and Roelofs, G. J.: Simulation of the tropospheric sulfur cycle in a global climate model, Atmos. Environ., 30, 1693-1707, 1996.

Ginoux, P., Horowitz, L. W., Ramaswamy, V., Geogdzhayev, I. V., Holben, B. N., Stenchikov, G., and Tie, X.: Evaluation of aerosol distribution and optical depth in the geophysical fluid dynamics laboratory coupled model $\mathrm{cm} 2.1$ for present climate, J. Geophys. Res.-Atmos., 111, D22210, doi:10.1029/2005JD006707, 2006.

Giorgi, F., Bi, X. Q., and Qian, Y.: Indirect vs. direct effects of anthropogenic sulfate on the climate of east asia as simulated with a regional coupled climate-chemistry/aerosol model, Clim. Change, 58, 345-376, 2003.

Gunther, A. J.: A chemical survey of remote lakes of the Alagnak and Naknek river systems, Southwest Alaska, USA, Arctic Alpine Res., 24, 64-68, 1992.

Hao, J. M., Wang, S. X., Liu, B. J., and He, K. B.: Plotting of acid rain and sulfur dioxide pollution control zones and integrated control planning in china, Water Air Soil Poll., 130, 259-264, 2001.

Heald, C. L., Jacob, D. J., Park, R. J., Alexander, B., Fairlie, T. D., Yantosca, R. M., and Chu, D. A.: Transpacific transport of Asian anthropogenic aerosols and its impact on surface air quality in the United States, J. Geophys. Res.-Atmos., 111, D14310, doi:10.1029/2005JD006847, 2006.

Hilst, G. R.: Proportionality between $\mathrm{SO}_{2}$ emissions and wet $\mathrm{SO}_{4}^{2}$ concentrations: the effect of area of averaging, Atmos. Environ. A-Gen., 26, 1413-1420, 1992.

Horowitz, L. W., Walters, S., Mauzerall, D. L., Emmons, L. K., Rasch, P. J., Granier, C., Tie, X. X., Lamarque, J. F., Schultz, M. G., Tyndall, G. S., Orlando, J. J., and Brasseur, G. P.: A global simulation of tropospheric ozone and related tracers: Description and evaluation of Mozart - Version 2, J. Geophys. Res.-Atmos., 108(D24), 4784, doi:10.1029/2002JD002853, 2003.

Horowitz, L. W.: Past, present, and future concentrations of tropospheric ozone and aerosols: methodology, ozone evaluation, and sensitivity to aerosol wet removal, J. Geophys. Res.-Atmos., 111, D22211, doi:10.1029/2005JD006937, 2006.

Jaffe, D., Tamura, S., and Harris, J.: Seasonal cycle and composition of background fine particles along the West Coast of the US, Atmos. Environ., 39, 297-306, 2005.

Klimont, Z., Cofala, J., Schopp, W., Amann, M., Streets, D. G., Ichikawa, Y., and Fujita, S.: Projections of $\mathrm{SO}_{2}, \mathrm{NO}_{\mathrm{x}}, \mathrm{NH}_{3}$ and VOC emissions in East Asia up to 2030, Water Air Soil Pollut., 130, 193-198, 2001.

Koch, D., Bond, T. C., Streets, D., and Unger, N.: Linking future aerosol radiative forcing to shifts in source activities, Geophys. Res. Lett., 34, L05821, doi:10.1029/2006GL028360, 2007a.

Koch, D., Bond, T. C., Streets, D., Unger, N., and van der Werf, G. R.: Global impacts of aerosols from particular source regions and sectors, J. Geophys. Res.-Atmos., 112, D02205, doi:10.1029/2005JD007024, 2007b.

Kritz, M. A., Le Roulley, J. C., and Danielsen, E. F.: The china clipper: Fast advective transport of radon-rich air from the asian boundary layer to the upper troposphere near California, Tellus B, 42, 46-61, 1990.
Levy, H., Schwarzkopf, M. D., Horowitz, L. W., Ramaswamy, V., and Findell, K.: Strong sensitivity of late 21 st century climate to projected changes in short-lived air pollutants, J. Geophys. Res.Atmos., 113, D06102, doi:10.1029/2007JD009176, 2008.

Liu, H. Y., Jacob, D. J., Bey, I., Yantosca, R. M., Duncan, B. N., and Sachse, G. W.: Transport pathways for Asian pollution outflow over the Pacific: interannual and seasonal variations, J. Geophys. Res.-Atmos., 108(D20), 8786, doi:10.1029/2002JD003102, 2003.

Liu, J. F. and Mauzerall, D. L.: Estimating the average time for inter-continental transport of air pollutants, Geophys. Res. Lett., 32, L11814, doi:10.1029/2005GL022619, 2005.

Liu, J. F., Mauzerall, D. L., and Horowitz, L. W.: Analysis of seasonal and interannual variability in transpacific transport, J. Geophys. Res.-Atmos., 110, D04302, doi:10.1029/2004JD005207, 2005.

Liu, J. F. and Mauzerall, D. L.: Potential influence of inter-continental transport of sulfate aerosols on air quality, Environ. Res. Lett., 2, 045029, doi:10.1088/17489326/1082/1084/045029, 2007.

Marmer, E., Langmann, B., Fagerli, H., and Vestreng, V.: Direct shortwave radiative forcing of sulfate aerosol over Europe from 1900 to 2000, J. Geophys. Res.-Atmos., 112, D23S17, doi:10.1029/2006JD008037, 2007.

Martin, L. R. and Damschen, D. E.: Aqueous oxidation of sulfurdioxide by hydrogen-peroxide at low ph, Atmos. Environ., 15, 1615-1621, 1981.

Moldan, F., Wright, R. F., Lofgren, S., Forsius, M., Ruoho-Airola, T., and Skjelkvale, B. L.: Long-term changes in acidification and recovery at nine calibrated catchments in Norway, Sweden and Finland, Hydrol. Earth Syst. Sc., 5, 339-349, 2001.

NAPAP: National Acid Precipitation Assessment Program Report to Congress: an integrated assessment, Washington D.C., USA, available at: http://ny.cf.er.usgs.gov/napap/Information/ NAPAP\%20Report\%208-22-05.pdf, 2005.

Olivier, J. G. J., Bouwman, A. F., van der Maas, C. W. M., Berdowski, J. J. M., Veldt, C., Bloos, J. P. J., Visschedijk, A. J. H., Zandveld, P. Y. J., and Haverlag, J. L.: Description of edgar version 2.0: a set of global emission inventories of greenhous gases and ozone-depleting substances for all anthropogenic and most natural sources on a per country basis and on 1ox1o grid, National Institute of Public Health and the Environment, The Netherlands, (RIVM) report no. 771060771002 / TNO-MEP report no. R771096/771119. , 1996.

Oppenheimer, M., Epstein, C. B., and Yuhnke, R. E.: Acid deposition, smelter emissions, and the linearity issue in the Western United States, Science, 229, 859-862, 1985.

Park, R. J., Jacob, D. J., Field, B. D., Yantosca, R. M., and Chin, M.: Natural and transboundary pollution influences on sulfate-nitrate-ammonium aerosols in the United States: implications for policy, J. Geophys. Res.-Atmos., 109, D15204, doi:10.1029/2003JD004473, 2004.

Pope, C., Burnett, R., Thun, M., Calle, E., Krewski, D., Ito, K., and Thurston, G.: Lung cancer, cardiopulmonary mortality, and longterm exposure to fine particulate air pollution, JAMA-J. Am. Med. Assoc., 287, 1132-1141, 2002.

Pope, C., Burnett, R., Thurston, G., Thun, M., Calle, E., Krewski, D., and Godleski, J.: Cardiovascular mortality and long-term exposure to particulate air pollution: epidemiological evidence 
of general pathophysiological pathways of disease, Circulation, 109, 71-77, 2004.

Prospero, J. M.: The atmospheric transport of particles to the ocean, in: Particle flux in the ocean, Scope 57, edited by: Ittekkot, V., Schäfer, P., Honjo, S., and Depetris, P. J., Wiley, New York, USA, 19-52, 1996.

Prospero, J. M., Savoie, D. L., and Arimoto, R.: Long-term record of nss-sulfate and nitrate in aerosols on Midway Island 19812000: evidence of increased (now decreasing?) anthropogenic emissions from Asia, J. Geophys. Res.-Atmos., 108(D1), 4019, doi:10.1029/2001JD001524, 2003.

Schwartz, J., Coull, B., Laden, F., and Ryan, L.: The effect of dose and timing of dose on the association between airborne particles and survival, Environ. Health Persp., 116, 64-69, 2008.

Seinfeld, J. H. and Pandis, S. N.: Atmospheric chemistry and physics: from air pollution to climate change, Wiley, New York, USA, 1326 pp., 1998.
Stohl, A.: A 1-year lagrangian "climatology" of airstreams in the Northern Hemisphere troposphere and lowermost stratosphere, J. Geophys. Res.-Atmos., 106, 7263-7279, 2001.

Stohl, A., Eckhardt, S., Forster, C., James, P., and Spichtinger, N.: On the pathways and timescales of intercontinental air pollution transport, J. Geophys. Res.-Atmos., 107(D23), 4684, doi:10.1029/2001JD001396, 2002.

Streets, D. G.: Dissecting future aerosol emissions: warming tendencies and mitigation opportunities, Climatic Change, 81, 313330, 2007.

Tie, X., Brasseur, G., Emmons, L., Horowitz, L., and Kinnison, D.: Effects of aerosols on tropospheric oxidants: a global model study, J. Geophys. Res.-Atmos., 106, 22 931-22 964, 2001.

Tie, X., Madronich, S., Walters, S., Edwards, D. P., Ginoux, P., Mahowald, N., Zhang, R. Y., Lou, C., and Brasseur, G.: Assessment of the global impact of aerosols on tropospheric oxidants, J. Geophys. Res.-Atmos., 110, D03204, doi:10.1029/2004JD005359, 2005. 